\title{
Child Testimony and Its Admissibility in Criminal Proceedings: A Comparative Analysis Between Common Law and Islamic Law Systems
}

\author{
Sowed Juma Mayanja \\ Faculty of Law and Shariah, Zanzibar University P.O Box 2440, Zanzibar, Tanzania.
}

\begin{abstract}
Despite all International and National efforts to safeguard the child, a number of children worldwide are facing sexual abuses, some of which are committed by their near relatives or caregivers. The matter, however, gets worse when there is no any other evidence to implicate the offender in courts of law except the testimony of the child who is the victim of the offence. This paper examines the admissibility of child testimony in criminal proceedings and its effect in implicating the offender. It makes a comparative analysis of the Common law and Islamic law systems. It analyses the conditions stipulated for the admissibility of child testimony in both systems and comes up with proposals to lighten some of those conditions so as to render justice to children who are victims of sexual offences by adults, yet such children do not meet the stipulated conditions.
\end{abstract}

Keywords: child testimony, sexual abuse, corroboration, voire dire, Aql, Bulugh, oath, conviction.

DOI: $10.7176 / \mathrm{JLPG} / 84-13$

Publication date: April $30^{\text {th }} 2019$

\section{Introduction}

The UN Convention on the Rights of the Child (CRC) 1989 stresses that the best interest of the child shall be a primary consideration in all undertakings concerning children whether undertaken by public or private social welfare Institutions, courts of law, administrative authorities or legislative bodies. ${ }^{1}$

In the same vein, the African Charter on the Rights and Welfare of the Child states that: "In all actions concerning the child undertaken by any person or authority, the best interests of the child shall be the primary consideration." It goes on to stress that: "In all judicial or administrative proceedings affecting a child who is capable of communicating his or her own view, an opportunity shall be provided for the view of the child to be heard either directly or through an impartial representative as a party to the proceedings, and those views shall be taken into consideration by the relevant authority in accordance with the provisions of appropriate law." 3

In Article 16 (1), the same charter states that: "State parties to the Charter shall take legislative, administrative, social and educational measures to protect the child from all forms of torture, inhuman or degrading treatment and especially physical or mental injury or abuse, neglect or maltreatment including sexual abuse, while in the care of a parent, legal guardian or school authority or any other person who has the care of the child."

Despite all these efforts to safeguard the child, a number of children worldwide are facing sexual abuses, some of which are committed by their near relatives or caregivers. ${ }^{4}$ The matter, however, gets worse when there is no any other evidence to implicate the offender in courts of law except the testimony of the child who is the victim of the offence.

This paper examines the admissibility of the testimony of a child in criminal proceedings and its effect in implicating the offender. It makes a comparative analysis of the Common law and Islamic law systems.

\section{Definition of a child}

The UN Convention on the Rights of the Child (CRC) defines a child as any person under the age of 18 unless individual nations recognize adulthood earlier. ${ }^{5}$

The African Charter on the Rights and Welfare of the Child defines a child as every human being below the age of 18 years. ${ }^{6}$

\footnotetext{
${ }^{1}$ Article 3 (1) of the CRC of 1989.

${ }^{2}$ Article 4 (1) of the African Charter of 1990.

${ }^{3}$ Ibid 4 (2).

${ }^{4}$ See: UN Report on Violence against Children, 2006, available at: https://www.unicef.org/violencestudy/reports/SG_accessed on 10th Feb. Feb. 2019.

See also: UNICEF Report on Sexual Violence Against Children in the Caribbean, 2012, available at:

https://www.unicef.org/easterncaribbean/ECAO_sexual_violence_againstChildren_in_Caribbean pdf, accessed on $10^{\text {th }}$ Feb. 2019.

See also: Save the Children's Child Protection Strategy $2013-2015$, available at:

https://www.savethechildren.net/sites/default/files/cp_strategy_final_web_emaill.pdf, accessed on 10 $0^{\text {th }}$ Feb. 2019.

${ }^{5}$ Article 1 of the CRC of 1989.

${ }^{6}$ Article 2 of the African Charter on the Rights and Welfare of the Child of 1990.
} 
The Law of the Child Act of Tanzania defines a child as a person below the age of eighteen years. ${ }^{1}$

This, therefore, means that every person under eighteen years is a child under the above laws.

According to Islamic Law, a child is a person who has not attained puberty. Puberty can be attained through a number of signs, for example, growing pubic hair in both males and females, menstruation in females, and wet dreams and change of voice in males. However, these signs vary from person to person, i.e. some persons see these signs at an early stage, yet others see them at a late stage, like some girls start menstruation at an age of nine, yet others start at the age of fifteen and above.

Under Islamic law, two attributes must be available for a person to become Mukallaf, (one who is under obligation of the law) and these are Bulugh (maturity), which is attained by puberty, and Aql (discretion) which is attained by growth except under abnormal situations like in one whose brain is impaired. These two attributes, i.e. Bulugh and Aql, form what is known as Illah of Hukum (the attribute on which the law is tied). However, the Illah of Hukum must be constant and should not vary from person to person. That's why Muslim Jurists have determined the age of puberty which is constant instead of the signs which vary from person to person. Imam Malik, Imam Shafi'e and Imam Ahmad opine that a child becomes an adult by attaining the age of 15 years whether is a male or a female. But according to Imam Abu Hanifah, a male child becomes an adult by attaining the age of 18 years, whereas a female becomes an adult by attaining the age of 17 years. ${ }^{2}$

Muslim scholars are however unanimous that discretion begins at the age of seven years. This is based on the hadith of the Prophet (S.A.W) which says: "Tell your children to start praying when they attain the age of seven years." 3

\section{Admissibility of testimony of a child}

There is no contention in common law on admissibility of testimony of a child who is fifteen years old and above. The contention however arises in accepting the testimony of a child of tender years.

However, there is no statutory definition of a child of tender years; but the courts of law have held that it means in the absence of special circumstances, any child of an age or apparent age of 14 years. Thus, in the case of Solomon Ouma v. R. $^{4}$, it was held, inter alia, that in the absence of special circumstances, the child of tender years is of an age or apparent age of 14 years.

Section 127 of the Evidence Act of Tanzania, Cap.6 of 1967, provides:

1) All persons shall be competent to testify unless the court considers that they are prevented from understanding the questions put to them, or from giving rational answers to those questions by reason of tender years, extreme old age, disease (whether of body or mind) or any other similar cause.

2) Where in any criminal cause or matter any child of tender years called as a witness does not, in the opinion of the court, understand the nature of an oath, his evidence may be received, though not given upon oath or affirmation, if in the opinion of the court, to be recorded in the proceedings, he is possessed of sufficient intelligence to justify the reception of his evidence, and understands the duty of telling the truth, provided that where evidence is received by virtue of this subsection given on behalf of the prosecution, the accused shall not be liable to be convicted unless such evidence is corroborated by some other material evidence in support thereof implicating the accused.

This, therefore, means that when a child of tender years appears as a witness, the judge or magistrate before hearing his evidence must satisfy himself that the child understands the nature of an oath. ${ }^{5}$ This position was well explained in the case of Jisho and Another v. R. ${ }^{6}$ :

The rule as laid down by the Court of Appeal in the case of Kibangany Arap Kolili v. R. (1959) E.A. 92 is that before a child is sworn in order to give evidence, the court must investigate in order to ascertain whether that child understands the nature of the oath.

If he does understand the nature of an oath, then the child may be sworn or affirmed. If however, it is found that the child does not understand the nature of an oath, the judge or magistrate must satisfy himself that the child is sufficiently intelligent to justify the receiving of his evidence and that he understands the duty of speaking the truth. ${ }^{7}$

An oath has been defined as a solemn declaration, accompanied by a swearing to God that one's statement is true or that one will be bound to a promise. The person making the oath implicitly invites punishment if the

\footnotetext{
${ }^{1}$ Section 4 (1) of the Law of the Child Act of Tanzania, Cap 21 of 2009.

${ }^{2}$ Oudar, A. Q., (2010), Criminal Law of Islam, New Delhi, Adam Publishers and Distributors, Vol. 2, p. 330. See also: Anwarullah, (2004),

Principles of Evidence in Islam, $2^{\text {nd }}$ Edition, Kuala Lumpur, A.S. NOORDEEN, p. 5.

${ }^{3}$ Abu Daud, (undated) Sunan, Beirut, Dar Al-Kitaab Al-Arabi, Vol. 1, p. 185, Hadith no. 495

4 (1978) LRT no. 53

${ }^{5}$ Massawe, A. A. F., (2004), The Burden of Proof; How to Defend Yourself in Criminal Cases, $1^{\text {st }}$ Edition, Mzumbe, Institute of Development Management, Mzumbe University, p. 79.

${ }^{6}$ (1971) H.C.D. n. 131

${ }^{7}$ Sarker, M. C., (2009), Sarker'sLaw of Evidence, $16^{\text {th }}$ Edition, Haryana, Lexis Nexis Butterworths Wadhwa Nagpur, Sec. 118, p.2125. See also: Morris, H. F., (1968), Evidence in East Africa, London, Sweet \&Maxwell, p.181.
} 
statement is untrue or the promise is broken. ${ }^{1}$

The legal effect of an oath is to subject the person to penalties for perjury if the testimony is false. ${ }^{2}$

\section{Determining the competence of a child as a witness}

The question of determining the competence of a child as a witness is decided by the judge or magistrate. For this purpose, the judge may hold a preliminary examination of the witness. The examination is known as voire dire test. The test does not necessitate the involvement of any medical doctor, nor does it require any medical measures, but ascertained by gathering the logical responses of the child to the questions asked. In addition to questioning the potential witness during the voire dire, the trial court may also hear testimony from parents, teachers, and others, provided it is helpful. ${ }^{3}$

It should be observed that a voire dire test is undertaken in order to determine the following issues:

a) Whether a child of tender years is possessed of sufficient intelligence to testify,

b) Whether the child understands the duty to tell the truth, and

c) Whether the child knows the meaning of an oath.

In the case of Fransisio Matovu $\boldsymbol{v}_{.} \boldsymbol{R}^{4}{ }^{4}$, the appellant had been convicted of murder by the High Court of Uganda. One of the witnesses was a child of 8 years who had been allowed to give unsworn evidence. However, there was no finding on record on the boy's intelligence and understanding of the duty to speak the truth. The Court of Appeal for East Africa held, among other things, that the trial Judge should himself question the child in order to ascertain whether the child understands the nature of an oath and is possessed of sufficient intelligence to justify reception of his evidence and understands the duty of telling the truth.

In the English case $\boldsymbol{R}$. v. Holmes ${ }^{5}$, the Judge was satisfied that the child had the capacity to give sworn evidence, after being asked "what becomes of a person who tells lies under oath?" The child responded "If he tells lies he will go to the wicked fire".

Where the witness is a child of tender years of age, a voire dire test is mandatory, and failure of the court in this regard diminishes the value of the evidence so recorded and might result in the conviction not being sustained on appeal.

In the case of Dhahir Ally v. $\boldsymbol{R}^{6}$, the High Court of Tanzania quashed the conviction of the appellant on the ground that it was based on unsworn evidence of children and voire dire examination had not been conducted properly or had been omitted.

However, since there is no provision stipulating what kind of questions should be asked in a voire dire examination, the courts often use their own discretion to choose the quality and nature of questions they deem to be fit to verify the competence of the child to adduce evidence. If the court is satisfied that the child called as a witness possesses sufficient intelligence and appreciates the obligation to tell the truth, it allows his or her evidence to be recorded upon oath if he or she understands the nature of an oath, or without oath if he or she does not understand the nature of an oath. ${ }^{7}$

\section{Corroboration of the un-sworn Evidence}

It is a settled principle of law that the unsworn testimony of a child cannot be relied on for conviction unless it is corroborated. ${ }^{8}$ Thus, in the case of Azaria s/o Mbuya $\boldsymbol{v} . \boldsymbol{R} \cdot{ }^{9}$, it was stated that unsworn testimony of a child must be corroborated.

In the case of Solomon Ouma $v . R^{10}$, it was held that:

i. Evidence of a child of tender years requires corroboration in both criminal and civil cases.

ii. Corroboration is additional independent evidence which connects the accused with the crime.

iii. In the absence of special circumstances, the child of tender years is of an age or apparent age of 14 years.

iv. The competence of a child of tender years to testify is a matter to be determined by the court from his/her capacity to understand and give rational answers to questions asked by the court.

In Idefonce Mpendakazi $\boldsymbol{v} . \boldsymbol{R}{ }^{11}$, the accused was convicted of cattle theft. A confession which the accused made before an Assistant Village Executive Officer was admitted in evidence. The only other prosecution evidence was the testimony of a twelve year old boy. It was held, inter alia, that the testimony of the boy required

\footnotetext{
${ }^{1}$ Garner, B. A., (2004), Black's Law Dictionary, $8^{\text {th }}$ Edition, Thomson West, p.1101.

${ }^{2}$ Ibid.

${ }^{3}$ Makame, M.H., (2016), The Child \& The Law, Some Basic Issues, $1^{\text {st }}$ Edition, Zanzibar, p.71.

${ }^{4}$ (1961) E.A. 260

5 (1861) 175 E.R. 1286

${ }^{6}$ (1989) T L R, 27.

${ }^{7}$ See Sec. 127 (2) 0f the Evidence Act of Tanzania.

${ }^{8}$ Sec. 127 (2) 0 f the Evidence Act of Tanzania.

9 (1968) H.C.D. n. 33.

${ }^{10}$ (1978) LRT no. 53

${ }^{11}$ (1967) H.C.D. n. 124.
} 
corroboration and would not support a conviction.

In R. v. Campbell ${ }^{1}$, Lord Goddad said:

"The sworn evidence of a child need not as a matter of law be corroborated but a jury should be warned not that they must find corroboration but that there is a risk in acting on uncorroborated evidence of young boys and girls though they may do so if convinced that the witness is telling the truth and this warning should also be given where a young boy or girl is called to corroborate the evidence either given by another child, sworn or unsworn, or of an adult."

\section{Age of competency of a child witness}

As mentioned earlier, there is no contention on admissibility of testimony of a child of tender years, and tender years has been determined by courts of law to mean an age or apparent age of 14 years. The contention is on the admissibility of testimony of a child who is below 14 years old.

Minor, in his textbook on the Law of Evidence, observes that at one time, the age of a child was considered as the criterion of his competence and it was a general rule that none could be admitted under the age of nine years, very few under the age of ten. ${ }^{2}$ But of late no particular age is required in practice to render the evidence of a child admissible. The competency of children is now regulated no by their age but by the degree of understanding which they appear to possess. ${ }^{3}$ A child may be a competent witness to give evidence in court if it appears that she can understand the questions put to her and give rational answers thereto. No precise age is fixed by law, within which children are absolutely excluded from giving evidence on the presumption that they have not sufficient understanding. In all questions of this kind much depends upon the good sense and discretion of the judge. In practice, it is usual to receive the testimony of children of eight or nine years of age, when they appear to possess sufficient understanding. ${ }^{4}$

This is exactly what Justice Lake of North Carolina court observed in State v. Turner ${ }^{5}$, as he said thus:

"There is no age below which one is incompetent, as a matter of law, to testify. The test of competence is the capacity of the proposed witness to understand and to relate under the obligation of an oath facts which will assist the Jury in determining the truth of the matter as to which it is called upon to decide.

This is a matter which rests in the sound discretion of the trial judge in the light of his examination and observation of the particular witness."

In the case of Mohamed Sugal v. The King ${ }^{6}$, a girl not more than ten years old was tendered by the Crown as the only eye witness at the trial of the accused for murder. The trial judge found that she was competent to testify as she appeared to be intelligent for her age and gave her answers frankly and without hesitation but she was not able to understand the nature of an oath. It was held that such unsworn evidence was admissible in the circumstances of the case.

\section{Testimony of children under Islamic Law}

Muslim jurists are of two different views with regard to testimony of a child:

The first view is that his testimony is not admitted in all cases. This is the view of the majority, including Imam Abuhanifa, Imam Shafie, and one of the views of Imam Ahmad. ${ }^{7}$

They base this view on the Qur'an, the Sunnah and Reasoning.

From the Qur'an, they quote the following verses:

a) (And get two witnesses out of your own men, and if there are not two men available, then a man and two women $)^{8}$ They argue that children are neither men nor women, and therefore they cannot be witnesses as directed by the verse.

b) (And take as witness two just persons from among you $)^{9}$ They contend that children are not yet just persons, and therefore cannot be witnesses.

c) (And conceal not the testimony for he who conceals it, surely his heart is sinful) ${ }^{10}$ They argue that children are not included in the verse as they have not reached the age of maturity for their hearts to be sinful.

From the Sunnah, they quote the Hadith of the Prophet (S.A.W) in which he said: "The pen was lifted from

\footnotetext{
${ }^{1}$ (1956) 2 Q.B. 432, C.C.A

${ }^{2}$ Monir, M. (2006), Textbook on the Law of Evidence, $7^{\text {th }}$ Edition, New Delhi, Universal Law Publishing Company. Pvt. Ltd, p. 325.

${ }^{3}$ Ibid.

${ }^{4}$ Ibid, pg. 326

5 (1966) 268 N.C. $255,230$.

${ }^{6}$ (1945) 48 Bom LR 138 (PC).

${ }^{7}$ Ibn Rushid, M. A., (1995), Bidayatul Mujtahid, $1^{\text {st }}$ Edn. Cairo, Dar Assalaam, Vol. 4, p. 2297. See also: Zaidani, A., (1997), Nithwam AlQadha Fi Ashariat Al-Islamiyyah, $3^{\text {rd }}$ Edn, Beirut, Muassasat Ar-Risaalah, p.149, Saedon, M., (1996), An Introduction to Islamic Law of Evidence, $1^{\text {st }}$ Edn. Hizbi, Shah Alam, p.56.

${ }^{8}$ Surat Al-Baqarah $(2: 282)$

${ }^{9}$ Surat At-Talaaq (65:2)

${ }^{10}$ Surat Al-Baqarah $(2: 283)$
} 
three people: the sleeping person until he wakes up, the child until he becomes mature, and the madman until he regains his understanding." This means that the three persons are not legally responsible for their words and actions while still in that state. Therefore, a child cannot be competent to testify.

They also quote another Hadith of the Prophet in which he said: "Ward off Huduud punishments whenever there is any doubt."2 They say that the child's testimony is doubtful and therefore it cannot be accepted in Huduud cases.

From reasoning; they say that a child does not fear to tell lies as he does not know the consequence of telling lies. He is also easily subjected to mistakes and forgetfulness in his testimony. His testimony is therefore unreliable and unaccepted.

The second view is that the testimony of a child is admitted in homicide and injury cases (assaults and battery) on the following conditions:

a) They should be two and above

b) They should have attained the age of discernment (mumayyiz), i.e. seven years and above.

c) The testimony should be given before they leave the scene of the incident.

d) There should have been no adult witnessing the incident.

e) The testimony should be given against another child and not against an adult. This is the view of Imam Malik and one of the views of Imam Ahmad. ${ }^{3}$

This view is based on necessity; in that if the testimony of a child is not admissible under such circumstances, then there would be no any other way of proving such cases as all other means of evidence are not available. ${ }^{4}$

\section{Discussion}

The evidence of a child witness has been looked at as dangerous and unreliable as children can easily forget or can easily tell lies. That is why many conditions have been put forward for its admissibility as compared to the evidence of an adult.

However, there is no scientific evidence that children are apparently no less honest than adults and no scientific evidence either that they are more likely than adults to make false accusation.

In the voire dire examination, there is no provision stipulating what kind of question should be asked, the courts often use their own discretion to choose the quality and nature of questions they deem to be fit to verify the competence of the child to adduce evidence. If the court is satisfied that the child tested has enough and sufficient ability to testify, it allows the child's evidence to be recorded either upon oath if he understands the nature of an oath, or without oath if he does not understand its nature. This approach, as Makame puts it, makes some confusion on which appropriate questions be asked to fulfill the conditions of voire dire examination. ${ }^{5}$

It may be observed that the application of too much formal method to determine the competence of the child is likely to make a child nervous and confused, especially when standing in the dock.

The competence enquiry, as Makame puts it, has historically been a critical challenge for children who are called to testify in cases pertaining to their victimization or in any other matters such as marital violence where they may have witnessed the scene of violence in their families. ${ }^{6}$

The principle that unsworn evidence of a child cannot be relied on for conviction unless it is corroborated is unjustified in cases of sexual abuse where the child witness is the victim of the offence and no other evidence to corroborate his/her testimony is available.

As for Islamic law, the second view which admits child testimony due to necessity appears to be the most appropriate as it protects the rights of children. However, the conditions set for the admissibility of child testimony are also very disturbing in cases where the child was the victim of sex abuse, was alone, had not attained seven years and the abuse was done by an adult.

The condition that the testimony should be given before leaving the scene of crime is also impractical, as children rarely disclose sexual abuse immediately after the event as they are usually threatened by the perpetrators with statements like "if you tell anyone I will kill you". The offence usually comes to the knowledge of parents after an elapse of time. Moreover, criminal cases usually take long to be heard and dispensed with in courts of law.

It's true that all these conditions, set by either common law or Islamic law, were intended for precautionary measures but should not be a means of defeating justice. We all agree that admitting child testimony is an abnormal situation, but when necessity arises, it knows no law. Under Islamic law, pork, dead animal, blood poured forth, are prohibited, but when there is dire necessity and the person is at the verge of death due to hunger, he is allowed

\footnotetext{
${ }^{1}$ Al-Bukhari, M.I., (1987), Swahiih Al-Bukhari, $3^{\text {rd }}$ Edition, Beirut, Daar Ibn Kathir, Vol.13, p.268.

${ }^{2}$ Ibn Baaz, A., (undated), Majmu'u Fataawah, Riyadh, Ar-Ria'st Al-A'mah Lil-Buhuth Al-Ilmiyyah Wal-Iftaah, Vol.25, p.263.

${ }^{3}$ Ibin Farhoon, I. A., (1986), Tabswirat Al-Hukkaam Fi Usul Al-Aqdhiyah, ${ }^{\text {st }}$ Edition, Vol.2, P. 32. See also: Ibn Al-Qayyim, M. A., (undated), At-Turuq Al-Hukmiyyah Fi As-Siyaasat Ashar'iyyah, Cairo, Matba’t Al-Madani, p. 252.

${ }^{4}$ Ibid.

${ }^{5}$ Makame, M.H., (2016), The Child \& The Law, p. 75

${ }^{6}$ Ibid p. 67.
} 
to eat any of them in order to save his life. This is what the Qur'an state in many verses, for example (He has forbidden you only meat of a dead animal, blood, the flesh of swine, and any animal which is slaughtered as a sacrifice for others than Allah. But if one is forced by necessity without willful disobedience, and not transgressing, then Allah is Oft-forgiving, most merciful) ${ }^{1}$

An Islamic legal maxim states that: "Necessity renders prohibited things permissible"2

Since the admissibility of child testimony is due to necessity, there is need to lighten the stringent conditions attached thereto so as to render justice to children who have been victims of sexual offences by adults yet such children do not meet the stipulated conditions.

\section{Conclusion}

From the foregoing discussion, it has been seen that child testimony is admitted in both common Law and Islamic Law but there are stringent conditions attached to its admissibility. It has been realized that there is need to relax some of these conditions especially in sexual offences committed against children because children who are victims of these offences are often vulnerable and frightened. Moreover, these offences are committed to the child in the absence of any adult except the perpetrator.

It is understandable that the conditions put on the admissibility of a child witness are precautionary measures so that the standard of proof in criminal cases is beyond reasonable doubt, but this precaution should not be a means of defeating justice. Hence the need to lighten the conditions attached to the admissibility of child testimony.

\section{REFERENCES}

\section{International Conventions}

African Charter on the Rights and Welfare of the Child, 1990.

Convention on the Rights of the Child (CRC), 1989.

\section{Statutes}

The Evidence Act of Tanzania, Cap.6, 1967.

The Law of the Child Act of Tanzania, Cap 21, 2009.

\section{Published books}

Abu Da'ud, Sulaiman Bin Al-Ash'ath, (undated), Sunan Abi Daud, Beirut, Daarul-Kitaab Al-Arabi.

Al-Hilaali, T. and Khan, M. (undated), Translation of the meaning of The Noble Qur'an [Madinah, King Fahd Complex for the printing of the Holy Qur'an.

Al-Bukhari, M.I., (1987), Swahiih Al-Bukhari, $3^{\text {rd }}$ Edition, Beirut, Daar Ibn Kathir.

Anwarullah, (2004), Principles of Evidence in Islam, $2^{\text {nd }}$ Edition, Kuala Lumpur, A.S. NOORDEEN.

Chandrachud, Y. V. \& Manohor, V. R., (2004), The Law of Evidence, $21^{\text {st }}$ Edition, New Delhi, Wadhwa and Company Nagpur.

Garner, B. A., (2004), Black's Law Dictionary, $8^{\text {th }}$ Edition, Thomson West.

Ibn Baaz, A., (undated), Majmu'u Fataawah, Riyadh, Ar-Ria'st Al-A'mah Lil-Buhuth Al-Ilmiyyah Wal-Iftaah.

Ibin Farhoon, I. A., (1986), Tabswirat Al-Hukkaam Fi Usul Al-Aqdhiyah, ${ }^{\text {st }}$ Edition

Ibn Al-Qayyim, M. A., (undated), At-Turuq Al-Hukmiyyah Fi As-Siyaasat Ashar'iyyah, Cairo, Matba't Al-Madani. Ibn Rushid, M. A., (1995), Bidayatul Mujtahid, $1^{\text {st }}$ Edn. Cairo, Dar Assalaam.

Makame, M. H., (2016), The Child \& The Law; Some Basic Issues, $1^{\text {st }}$ Edition, Zanzibar.

Massawe, A. A. F., (2004), The Burden of Proof; How to Defend Yourself in Criminal cases, Institute of Development Management, Mzumbe University.

Mayanja, S. J. (2014), Al-Qawa'id Al-Fiqhiyyah, The Islamic Legal Maxims, a Critical Analysis, $1^{\text {st }}$ Edition, Zanzibar, University College Press Chukwani

Monir, M. (2006), Textbook on the Law of Evidence, $7^{\text {th }}$ Edition, New Delhi, Universal Law Publishing Company. Pvt. Ltd.

Morris, H. F., (1968), Evidence in East Africa, London, Sweet \&Maxwell.

Oudar, A. Q., (2010), Criminal Law of Islam, New Delhi, Adam Publishers and Distributors.

Saedon, M., (1996), An Introduction to Islamic Law of Evidence, $1^{\text {st }}$ Edn. Hizbi, Shah Alam.

Sarker, M. C., (2009), Sarker's Law of Evidence, $16^{\text {th }}$ Edition, Haryana, Lexis Nexis Butterworths Wadhwa Nagpur.

Zaidani, A., (1997), Nithwam Al-Qadha Fi Ashariat Al-Islamiyyah, $3^{\text {rd }}$ Edn, Beirut, Muassasat Ar-Risaalah.

\footnotetext{
${ }^{1}$ Surat An-Nahl (16:115)

${ }^{2}$ Mayanja, S. J. (2014), Al-Qawa'id Al-Fiqhiyyah, The Islamic Legal Maxims, a Critical Analysis, $1^{\text {st }}$ Edition, Zanzibar, University College Press Chukwani, pg. 40.
} 


\section{Websites:}

https://www.unicef.org/violencestudy/reports/SG

https://www.unicef.org/easterncaribbean/ECAO_sexual_violence againstChildren_in_Caribbean

https://www.savethechildren.net/sites/default/files/cp_strategy_final_web_email 